\title{
Comparison of Social Status of British and Chinese Women in the Era of Pride and Prejudice
}

\author{
Lu Chen \\ Huanghe Science and Technology College \\ Zhengzhou, China 450000
}

\begin{abstract}
Pride and Prejudice is masterpiece of feministic literature as well as representative work that fully reflects awakening of feminist consciousness and social status of women in British society in the $18^{\text {th }}$ and $19^{\text {th }}$ centuries. The reality of marriage and love of ladies in this book can fully show social status and ideology of women at that time. Chinese women as representatives of oriental women in the same era are under the oppression of feudal ethical codes and have more severe social status and current living situation.
\end{abstract}

Keywords-feminist consciousness; social status; feminist movement

\section{INTRODUCTION}

Pride and Prejudice is a classical work on history of British literature. It is also a representative work that fully reflects awakening of feminist consciousness and social status of women in British society in the 18th and 19th centuries. The author Jane Austen finished the first draft in 1797. It was published in 1813 after several times of modification. The author became a middle-aged woman writer, who once experienced failure of sentimental first love and devoted to writing and then made a living through writing. She published works but never got married. Pride and Prejudice inherits consistent writing theme of the author-marriage and love. Span of time of this work makes Pride and Prejudice do not become romantic depiction of inexperienced innocent girls for love, but become deep observation of mature female perspective of reality and predicament of marriage and love in British society at that time. It also contains profound thought of the author for ideal female image and varied marriage. The article compares social status and life value between British women and Chinese women as representative of oriental women in the 18th and 19th centuries.

\section{HistoricAl BACKGROUND OF PRIDE AND PREJUDICE}

Britain experienced transition period from feudal agricultural economy to capitalist market economy in the end of the 18th century and early 19th century. Capitalistic economy sprouted. The influences of it on the vast rural areas are limited. Old feudal relations and economic sector still occupied the dominant position. Rural economy was still important part of British economy. Landed families that have a large number of real estate such as the Bennett family and eupatrid from industrial city, such as Darcy and Bingley constitute an epitome of British society. As eupatrid, Darcy and Bingley have political privilege and abundant property inheritance and purchase real estate in the countryside to maintain privileged position in upper class. From attitudes of people toward Darcy and Bingley, we can also observe guarded hierarchy of British society at that time. Ideological value of people establishes on property ownership right. Economic and social reform changes life and personal experience of women, but politics, legal system, traditional consciousness and gender discrimination continue to maintain unequal social status between men and women. English history in the 19th century indicates that before Queen Victoria, Women did not have any social status. They did not have the right to vote, could not dominate their properties independently after getting married and did not have guardianship for their kids. Maidens of middle-class family cannot talk with men without parents beside them.

Some rights to legal recognition are obtained.

\section{INTERPRETATION OF THIS BOOK FOR SOCIAL STATUS OF BRITISH WOMEN}

\section{A. Economic Status of Women}

Under hierarchical patriarchy, in the 18th and 19th century, Britain protected rights and properties of men to some extent. Daughter had certain rights to inherit properties. For example, it writes in the book, "Mr. Wickham mainly covets the property of thirty thousand pounds of my sister", "Mrs Bennett and her children enjoy the legacy of five thousand pounds". But family property (including house and land, titles of nobility) can only inherited by male heirs to avoid loss and dispersion of family property, while female descendants can only inherit money. It writes in this book that Bennett family have limited right of inheritance of this house. The ancestor made legal documents and declared that all real estates of $\mathrm{Mr}$. Bennett can only be inherited by son. Because Mr. Bennett only has five daughters, the house is inherited by his nephew, a distant relative of him. So in his book, it writes, "she continues to shout abuse and says it is too cruel that the property cannot be inherited by her daughter but an outsider". The author makes a relentless compliant against the system that limits succession and deprives living rights of women through Mrs. Bennett. Under patriarchy at that time, men can acquire economic income through birthright, doing business, becoming priest, lawyer and joining the army. Because social status of women is low, they didn't have equal opportunity as men to 
receive education. Many ladies who want to receive education study at home. It restricts their ability to live and realize economic independence. At that time, the type of jobs for women was few, such as workwoman, housemaid and private teacher. Women in middle and upper class do not work. They will be despised if they go out to work. They often do handworks. In order to marry a rich husband, young ladies often make demand on themselves in accordance with standards put forward by men, just like the book writes, "A woman must be proficient in music, singing, drawing, dancing and modern language so that she can be called versatile. In addition, her appearance, gait, voice, intonation, style of conversation and expression must have characteristics, or she is ordinary". It shows that social initiative of women at that time was greatly restricted. It is very difficult for them to realize economic independence and control destiny. Even Elizabeth who was born in middle class could not inherit a large number of properties like Darcy's sister. It is also difficult for her to take the initiative in marriage. It was the dilemma faced by women at that time.

\section{B. Women and Marriage}

For women that could not realize economic independence at that time, it was the true reflection of their life that they depend on father before marriage and depend on husband after marriage. It was the ideal of most women to marry a rich husband at that time. In British society in the 18th and 19th centuries, compared with love, money and social status were necessities for a perfect marriage. It is reflected in the book. Mrs. Bennett wants to associate with noble bachelors Bingley and Darcy very much and hopes her daughters can marry them. She mentions properties inherited by Darcy and Bingley every time. While Bingley's sister and Darcy's aunt don't like Elizabeth and think daughters of the Bennett family can only inherit few properties, and Elizabeth and Darcy are not matched for marriage. Darcy breaks up Bingley and Elizabeth's sister Jane because of economic status of Jane. This shows that huge conflicts exist between ideal marriage of women and economic reality at that time. It is very difficult to have perfect love and marriage. It needs courage and knowledge of women to choose marriage and love according to their emotions. In this book, "Although marriage may not let people happy, it is the most appropriate home for women. It can prevent them from starving", it is the sad and helpless choice that cruel social reality compels women to make. In comparison, it is not difficult to see unusual insight and valued independence of emotion and personality of Elizabeth, the ideal woman shaped by Jane Austen.

\section{Feminist Consciousness and Feminine Value}

In the 18th and 19th centuries, women had low social status and were regarded as inferior to men on intelligence and ability. Women shall be obedient to father and husband of them. They shall focus their life on the family and all that they can do is to do housework. Under the circumstance that women cannot realize economic independence and have low social status, it is very difficult for them to break away from role identification in society and have independent consciousness and value. With the development of capitalism, the constraints of culture in European feudal society gradually loosen. Western feminist movement begins to sprout. Feminist consciousness is awakened. New schools of feministic literature appear. Except for Jane Austen, representative woman writers include the three Bronte sisters. From narrative perspective of this book, the narration of the story is mainly carried out by using omniscient perspective of third person. Jane Austen regards Elizabeth as core people of the book. The book also presents plots and people through observation of Elizabeth for the society. It makes the book highlight consciousness and standpoint of women. For example, after Elizabeth knows that Miss Lucas accepts the proposal of Mr. Collins, she shows pity for Miss Lucas and worry about sad inward world of her; after rejecting the first marriage proposal of Darcy, and receiving letter from him, Elizabeth reflects selfjudgment. These descriptions of consciousness of Elizabeth embody independent personality and keen outsight of her. It bases on the praise of Jane Austen for intelligence and knowledge of women. From the perspective of relationship between Elizabeth and Darcy, although gap exists between them on social status and wealth, the personality of Elizabeth is equal to that of Darcy. Her wise words and proper conduct attract Darcy deeply and make him eliminate restraint of social bias and overcome his arrogance, propose to Elizabeth for two times and finally marry her. The shaping of image of Elizabeth breaks definition of female role in traditional perspective and makes women no longer be the dependency of men nor object for desire of men. It shows high degree of self-confidence and independence. Men are no longer in the central position like the description in traditional culture. They begin to respect viewpoint and judgment of women. Jane Austen denies the difference between men and women on intelligence and emphasizes women have the same developed intelligence and rationality as men and can also play the role of instructor to point out defects in character of men. Works of Jane Austen discuss social problems from the perspective of women, including marriage, family and morality and have critical attitude towards male chauvinism. The standpoint of the author is also influenced by trend of social consciousness at that time, showing feminist consciousness and feminine value.

Women in British society in the 18th and 19th centuries are in the dilemma that it is difficult for them to realize economic independence and choose marriage according to their own emotions. Influenced by social change and enlightenment movement, feminist consciousness is awakened. Women begin to fight for speaking right and affirm their own value in patriarchal society, which have progressive significance.

\section{SituAtion OF CHINESE WOMEN IN THE 19TH CENTURY}

In the 19th century, China was still in feudal society. Some deep-rooted feudal bad customs are like the chains to constrain Chinese women. Song dynasty is the critical period for formation and development of Chinese feudal ethical code. Bad customs such as foot-binding and prohibition of remarriage that confine thinking of women and do physical and mental harm to women are handed down from Song dynasty until Qing dynasty. Because feudal thought thinks men enjoy higher status than women, girls are not out of favor more or from birth. It is common to see newborn baby girls are drowned or regarded as inferior to boys. Daughters of poor 
family cannot show their face in public. They can only do housework and toilsome things.

Girls are physically and mentally destroyed. When securing an official position in the Southern Song Dynasty, $\mathrm{Zhu} \mathrm{Xi}$ once ordered women to bind feet to keep distance from men. Later, it developed into the situation that it was not easy for girls to get married if they did not bind their feet. The bad custom does prolonged harm to girls. Feet-binding is bad custom left by the history for Chinese women in modern times. It shows that women are just plaything of men and embodies the occupation of men for women. It is the symbol that women are accessory of men. Under this circumstance, the body of women is abnormal and their thoughts are also morbid naturally.

In the long feudal society of China, women have the lowest social status, without personality or personal freedom. They have no rights to enjoy school education. Feudal ethical doctrines such as "wifely submission and virtue" and "A woman without talent is virtuous" and "Husband guides wife" make women benighted. Girls shall "be obedient to father before marriage and husband after marriage". They depend on men and do not have independent economic status. Their marriage is "the command of parents, the words of a matchmaker". No matter how the husband behaves, the wife must be loyal to husband, or she will be accused, laughed at and abused, even without a place to live in. At that time, stone arch will be erected by the government in honor of a chaste woman widowed at a young age. Feudal society requires women to be faithful to their husbands until her death and abide by moral codes. Even in The New Year's Sacrifice written by Lu Xun in the late Qing Dynasty and early Republic of China, although the heroine Xiang Linsao is very young, she wants to die to show chastity after her husband is died and her mother-in-law forces her to get married. It shows that feudal ethical codes greatly harm people's thoughts. Women are accessory of men. So Lu Xun angrily criticizes the feudal society that lasts for thousands of years.

\section{FEMINIST MOVEMENT IN BRITAIN IN THE 19TH CENTURY AND IDEOLOGICAL TREND OF WOMEN'S RightS IN CHINA IN EARLY 20TH CENTURY}

From the perspective of history, big differences exist between Chinese and British Women in living condition. Except for different culture and politics, it has large relationship with development of feminist movement. British women do not have any right in the 18th century. At the end of the 18th century, feminism appeared and sprouted in Britain. Feminist movement in Britain in the 19th century promoted some legislation. For example, the Act of Parliament passed in 1837 makes women get some legal rights; Property Right of Married Women finally won victory in 1882 through thirty years of struggle; female taxpayers got the right to vote municipal securities institutions in 1869 and had the right to become school board members. In 1900, women still did not have the right to vote, but they are freer than before. For example, they can open school for girls and do some jobs that they are forbidden to do before. Women organize their groups gradually and throw themselves to work in the society.
Feminist thought in China sprouted in late Qing Dynasty. Kang Youwei and Liang Qichao put forward "not binding feet" and "establishing girl schools", which were the start to realize equality of men and women. During the period of Constitutional Reform and Modernization, the slogan of "equality of men and women" was raised and popular. In 1898, Kang Youwei submitted Petition on Not Binding Feet to Guangxu Emperor and it was allowed to put into practice. In 1912 , complying with requirements of feminist movement and the masses, Sun Zhongshan, the provisional president of the republic of China, issued Order of Department of the Interior of Not Binding Feet for Implementation in All Provinces. At the beginning of the 20th century, "new women" who pursued freedom of marriage and yearn for new life made a figure. The rights of Chinese women on receiving education, studying abroad and making a living in society acquired unprecedented development. The Civil Law issued in December 1930 and implemented in May 1931 clearly states the female suffrage, right of inheritance, right of marriage by choice, right of freedom of remarriage, and prohibition of bigamous marriage of men.

Feminist movement in Britain is the representative of feminist movement in western countries. At early stage, most pushers of feminist movement in China knew about western civilization through missionary and absorbed quintessence of feminist movement in western countries and began to fight for women's liberation movement of China. As a representative work of feministic literature, Pride and Prejudice not only shows independent personality of women and their intelligence that is not inferior to men but also reveals dilemma of women in survival and marriage under patriarchal society in the 18th and 19th centuries. It appropriately reflects that feminist consciousness sprouts in British society at that time.

\section{REFERENCES}

[1] Huang Jing.2002. The embodiment of female consciousness in Pride and prejudice. Journal of Lanzhou University (SOCIAL SCIENCE EDITION) (6)

[2] Gao Ya.2010. Pride and Prejudice and British Social and Literary Education in the countryside (10)

[3] He Saibo\& Shen Dan.2013. Studies on female Bildungsroman from the perspective of Translation -- On Yang Bin's versions of Pride and Prejudice as an example. Foreign Language and Foreign Language Teaching (3)

[4] Shi Yan.2013. A study of women's marriage in the transitional periodthe comparison of the British female writers in the nineteenth Century and the Chinese female writers' novels in the twentieth Century. Journal of Changchun University of Science and Technology (3)

[5] Xiong Ying.2014. The study of the images of Chinese women in the nineteenth Century - focusing on The Chinese Repository. The Scientific Advisory (Technology Management) 